\title{
Transcriptional silencing of the inhibin- $\alpha$ gene in human gastric carcinoma cells
}

\author{
YOUNG IL KIM ${ }^{1,2}$, JAEJUN SHIM ${ }^{3}$, BYUNG-HO KIM ${ }^{3}$, SUNG JAE LEE ${ }^{4}$, \\ HA KYU LEE ${ }^{4}$, CHUNGHEE $\mathrm{CHO}^{5}$ and BYUNG-NAM $\mathrm{CHO}^{4}$
}

\begin{abstract}
${ }^{1}$ Medical Science Research Institute, Kyung Hee University Medical Center; ${ }^{2}$ East-West Medical Research Institute, Kyung Hee University; ${ }^{3}$ Department of Internal Medicine, Kyung Hee University School of Medicine, Seoul 130-872;

${ }^{4}$ Department of Life Sciences, The Catholic University of Korea, Bucheon 420-743; ${ }^{5}$ Department of Life Science,

Gwangju Institute of Science and Technology (K-JIST), Gwangju 500-712, Republic of Korea
\end{abstract}

Received January 26, 2012; Accepted April 6, 2012

DOI: 10.3892/ijo.2012.1472

\begin{abstract}
Although inhibin was first identified as a hormone regulating pituitary FSH secretion, it was later recognized to act as a tumor suppressor in the gonad and adrenal glands. Recently, the alpha subunit of this dimeric hormone (inhibin- $\alpha$ ) was reported to be involved in prostate tumorigenesis. To identify additional roles outside the reproductive axis, we investigated inhibin- $\alpha$ gene activity and subsequent cell fate in human gastric cancer cells. The results were as follows: all the gastric cancer cells had at least one of a set of abnormalities including hypermethylation of the promoter, mutation of the 5'-UTR or allelic imbalance including LOH in the inhibin- $\alpha$ gene. Hypermethylation of the promoter and mutation of the 5'-UTR in inhibin- $\alpha$ were observed in SNU-1, SNU-5 and SNU-484 cells. LOH was observed in AGS, KATO III, SNU-5, SNU-484 and SNU-668 cells. Treatment with 5-AzaC, a demethylating agent, induced demethylation of the inhibin- $\alpha$ promoter in the SNU-1, SNU-5 and SNU-484 cell lines, with the CpG5 site being strongly influenced by 5 -AzaC. In addition, inhibin- $\alpha$ mRNA and protein were maintained at low levels in most of the gastric cancer cell lines. These low levels of mRNA and protein expression could be increased in most lines by treatment with 5-AzaC. These increased inhibin- $\alpha$ expression levels seemed to be closely associated with apoptosis and suppression of cell growth. Taken together, our results reveal that the inhibin- $\alpha$ gene is transcriptionally silenced in human gastric cancer cells, and that reactivation of the gene suppresses their growth characteristics. This suggests that inhibin- $\alpha$ may have a more general tumor suppressor activity outside the reproductive axis.
\end{abstract}

Correspondence to: Dr Byung-Nam Cho, Department of Life Sciences, The Catholic University of Korea, 43 Jibong-ro, Wonmi-gu, Bucheon-si, Gyeonggi-do 420-743, Republic of Korea

E-mail: ocean@catholic.ac.kr

Key words: inhibin- $\alpha$, hypermethylation, silencing, stomach

\section{Introduction}

Inhibins and activins, members of the transforming growth factor- $\beta$ (TGF- $\beta$ ) superfamily, are polypeptides that were originally isolated from ovarian fluid, based on their effect on pituitary follicle-stimulating hormone (FSH) production and secretion. Inhibins are heterodimers that are composed of a common $\alpha$ subunit and one of two homologous $\beta$ subunits ( $\beta_{\mathrm{A}}$ and $\left.\beta_{\mathrm{B}}\right)$. Activins are either heterodimers or homodimers of the inhibin $\beta$ subunits $\left(\beta_{A} \beta_{A}, \beta_{B} \beta_{B}\right.$, and $\left.\beta_{A} \beta_{B}\right)(1-3)$. Activin $\beta_{C}, \beta_{D}$, $\beta_{\mathrm{E}}$ chains, and partially characterized activin $\operatorname{AC}\left(\beta_{\mathrm{A}} \beta_{\mathrm{C}}\right)$ and activin $B C\left(\beta_{B} \beta_{C}\right)$ proteins have also been reported (4-6).

Besides their classical endocrine function in suppressing of FSH production and secretion, inhibins are thought to act in an autocrine or paracrine manner within reproductive tissues. In females, inhibins appear to influence folliculogenesis by regulating granulose cell maturation and proliferation, steroid hormone production and oocyte maturation within the ovary (7-10). Reduced production of inhibins or production of mutant forms of inhibins is linked to several ovarian diseases, including premature ovarian failure (11) and polycystic syndrome (12), whereas increased inhibin is found in pre-eclampsia (13) and in certain ovarian cancers $(14,15)$. Overexpression of inhibin- $\alpha$ in mice results in abnormal reproductive function including decreased litter size (16) and decreased embryo size (17). In males, inhibins are potential autocrine or paracrine regulators of Leydig and Sertoli cell proliferation, differentiation and steroidogenesis (18).

More recently, inhibins and activins have both been implicated in endocrine-related cancers (19). The inhibin- $\alpha$ gene was identified as a tumor suppressor gene in the gonads and adrenals by functional studies using knockout mice (20-22). This has raised the question of whether it plays a broader role as a tumor suppressor outside the reproductive axis. A second interesting model has been prostate carcinoma, where it was observed that hypermethylation of the inhibin- $\alpha$ gene promoter and $\mathrm{LOH}$ at $2 q 32-36$, the chromosome region harboring the inhibin- $\alpha$ gene, occurred in $42 \%$ of prostate carcinomas (23). Moreover, there was a positive correlation between loss of inhibin expression and malignancy of these human prostate carcinomas cells (24). 
Recently, seemingly conflicting functions of the inhibin- $\alpha$ gene in the prostate were reported. Inhibin- $\alpha$ expression was reduced in early-stage tumors but increased in late-stage, metastatic prostate cancers, suggesting that inhibins act as tumor suppressors during early tumorigenesis but might act as tumor promoters during late-stage disease $(24,25)$. Moreover, it was reported that inhibin negatively regulated matrix metalloproteinase (MMP) levels and MMPs have an integral role in the increased metastatic and invasive potential of cancer cells (26-28). Thus considerable evidence supports roles of inhibin- $\alpha$ beyond the gonad and adrenal gland and indicates its importance in regulating cell growth. Whether or not inhibin- $\alpha$ has a general function in cancerous cells and tissues other than prostate is not yet clear. Having the long-term goal of addressing this question, we studied inhibin- $\alpha$ gene expression changes in human gastric cancer carcinoma cells.

\section{Materials and methods}

Cell cultures. Human gastric cancer cell lines AGS and KATO III were purchased from the American Tissue Culture Collection (Manassas, VA, USA). SNU-1, SNU-5, SNU-16, SNU-484, SNU-601, SNU-638, SNU-668, and SNU-719 cell lines were supplied by the Korean Cell Line Bank (Cancer Research Center, Seoul, Korea). Cells were cultured in RPMI-1640 medium (Gibco-BRL, Carlsbad, CA, USA) containing 10\% fetal bovine serum (FBS), $100 \mathrm{U} / \mathrm{ml}$ penicillin and $100 \mu \mathrm{g} / \mathrm{ml}$ streptomycin at $37^{\circ} \mathrm{C}$ in a humidified atmosphere of $5 \% \mathrm{CO}_{2}$ in $95 \%$ air.

Bisulfite modification. The methylation status of the promoter CpG islands of the inhibin- $\alpha$ gene in all sample DNAs was analyzed by PCR on the sodium-bisulfite converted DNA (29). Genomic DNA was extracted by the Wizard Genomic DNA purification kit (Promega Corporation, Madison, WI, USA). DNA $(2 \mu \mathrm{g})$ in a volume of a $50 \mu \mathrm{l}$ was denatured with $\mathrm{NaOH}$ (final concentration, $0.2 \mathrm{M}$ ) and incubated at $37^{\circ} \mathrm{C}$ for $15 \mathrm{~min}$, then $30 \mu \mathrm{l}$ of $10 \mathrm{mM}$ hydroquinone and $520 \mu \mathrm{l}$ of $3 \mathrm{M}$ sodium bisulfite (Sigma-Aldrich, St. Louis, MO, USA) at pH 5.0 were added into the tube. After mixing, samples were incubated under mineral oil at $55^{\circ} \mathrm{C}$ for $16 \mathrm{~h}$. Then, DNA was desalted with Wizard DNA Clean-Up system (Promega), desulfonated by addition of $\mathrm{NaOH}$ (final concentration, $0.3 \mathrm{M}$ ), and incubated at $37^{\circ} \mathrm{C}$ for $15 \mathrm{~min}$. The solution was neutralized by addition of ammonium acetate (final concentration, 3.0 M), and the DNA was ethanol-precipitated, dried, and re-suspended in $20 \mu \mathrm{l}$ of water and used immediately or stored at $-20^{\circ} \mathrm{C}$.

Detection of methylation. Methylation was assessed by PCR and sequence analysis of bisulfite-treated DNA. The bisulfite reaction converted unmethylated cytosines to uracil, whereas methylated cytosines were unchanged. The 5'-UTR region of inhibin- $\alpha$ was amplified by nested PCR using primers designed to the bisulfite-converted sequence (23). Primer sequence 1 (5'-GATAAGAGTTTAGATTGGTTTTATTGGTT-3') and 2 (5'-ACACCATAACTCACCTAACCCTACTAATAA-3') were used for the first round of PCR and primer sequences 3 (5'-ACCCCTTCTACCAAAATCTACCCAAAA-3') and 4 (5'-GAAGGTGTTGTATGTTTGTATGTGTGAGTT-3') were used for the second round of PCR. The first round of PCR was performed in $25 \mu \mathrm{l}$ reactions with $2 \mu \mathrm{l}$ of bisulfite-converted
DNA, 1X PCR buffer (10 mM Tris, pH 8.3, $50 \mathrm{mM} \mathrm{KCl,} 1.5 \mathrm{mM}$ $\left.\mathrm{MgCl}_{2}\right), 200 \mu \mathrm{M}$ of each dNTPs, $10 \mathrm{pmol}$ of each primer 1 and 2, and 1 unit of AmpliTaq Gold DNA polymerase (Applied Biosystems, Carlsbad, CA, USA). PCR cycles consisted of $95^{\circ} \mathrm{C}$ for $15 \mathrm{~min}$ followed by 5 cycles of $95^{\circ} \mathrm{C}$ for $1 \mathrm{~min}, 50^{\circ} \mathrm{C}$ for $2 \mathrm{~min}$, and $72^{\circ} \mathrm{C}$ for $3 \mathrm{~min}$ and followed by 30 cycles of $95^{\circ} \mathrm{C}$ for $1 \mathrm{~min}$, $55^{\circ} \mathrm{C}$ for $2 \mathrm{~min}$, and $72^{\circ} \mathrm{C}$ for $2 \mathrm{~min}$ with a final incubation step of $72^{\circ} \mathrm{C}$ for $10 \mathrm{~min}$. A sample of $2 \mu \mathrm{l}$ from the first PCR was amplified in a $25 \mu \mathrm{l}$ reaction as above except that primer 3 and 4 were used. PCR cycling conditions were as for the first reaction, with the exception that the annealing temperature was increased to $60^{\circ} \mathrm{C}$. PCR products were gel purified, ligated into the PCR 2.1 cloning vector, and cloned using the $\mathrm{TOPO}^{\circledR}$ TA Cloning ${ }^{\circledR}$ Kit according to the manufacturer's instructions (Invitrogen, Carlsbad, CA, USA). For each PCR, 10 clones were sequenced and the methylation at each of the seven CpGs in the inhibin- $\alpha$ proximal promoter was determined.

DNA analysis. DNA was isolated from cultured cells by standard methods. Two regions of inhibin- $\alpha$ gene were amplified from genomic DNA by PCR with specific oligonucleotide primers (30). The first region of $240 \mathrm{bp}$ (fragment A), which includes $140 \mathrm{bp}$ of 5'-UTR and $100 \mathrm{bp}$ of exon 1, was amplified by primers AF (5'-GACTGGGGAAGACTGGATGA-3') and AR (5'-TCACCTTGGCCAGAACAAGT-3'). The second region of $396 \mathrm{bp}$ (fragment B), which comprises part of exon 2, was amplified by primers BF (5'-AGCAGCCTCCAATAGCT CTG-3') and BR (5'-AGCTCCTGGAAGGAGATGTTC-3'). Genomic DNA (200 ng) was amplified in a $50 \mu \mathrm{l}$ volume reaction containing $1 \mathrm{X}$ PCR buffer, $2 \mathrm{mM} \mathrm{MgCl}_{2}, 2.5 \% \mathrm{DMSO}$, $0.2 \mathrm{mM}$ of each dNTP, 20 pmol of each specific primer and 1.5 units of AmpliTaq Gold DNA polymerase. The condition for amplification was as follows: first after denaturation at $95^{\circ} \mathrm{C}$ for $14 \mathrm{~min}$, then denaturation at $95^{\circ} \mathrm{C}$ for $40 \mathrm{sec}$, annealing at $57^{\circ} \mathrm{C}$ for $30 \mathrm{sec}$, and extension at $72^{\circ} \mathrm{C}$ for $1 \mathrm{~min}$ for 35 cycles and final extension at $72^{\circ} \mathrm{C}$ for $7 \mathrm{~min}$. Polymorphism $-16 \mathrm{C}>\mathrm{T}$ in the $5^{\prime}$-UTR was screened in the samples by restriction enzyme analysis using SpeI (New England Biolabs, Ipswich, MA, USA). Briefly, fragment A was amplified by PCR and $5 \mu \mathrm{l}$ of purified PCR product was digested overnight at $37^{\circ} \mathrm{C}$ with 5 units of SpeI, electrophoresed on $8 \%$ polyacrylamide gels, stained with ethidium bromide and visualized by using a Gel Doc 1,000 Gel Documentation System (Bio-Rad, Hercules, CA, USA). Presence of the $240 \mathrm{bp}$ fragment indicated a homozygous variant for wild-type, whereas presence of two fragments of $120 \mathrm{bp}$ corresponded to homozygous variant T. Substitution $769 \mathrm{G}>\mathrm{A}$ of exon 2 was analyzed by digestion of fragment $\mathrm{B}$ with different restriction enzymes. Five microliters of purified PCR product was digested overnight at $37^{\circ} \mathrm{C}$ with 5 units of BsrFI (New England Biolabs) and analyzed as described above. The restriction site that renders two fragments of 340 and $56 \mathrm{bp}$ is abolished in the variant allele. In addition, $5 \mu \mathrm{l}$ of purified PCR product were digested overnight at $37^{\circ} \mathrm{C}$ with 5 units of Fnu4HI (New England Biolabs), electrophoresed on 15\% polyacrylamide gels, stained with ethidium bromide and visualized by image analysis. The $396 \mathrm{bp}$ fragment renders four fragments of 153, 107, 51, and $25 \mathrm{bp}$, among others of lower molecular weight, in the wild-type allele, whereas the allele with substitution $769 \mathrm{G}>\mathrm{A}$ renders four fragments of $153,107,76$ and $51 \mathrm{bp}$, among others of lower molecular weight. 
Loss of heterozygosity $(\mathrm{LOH})$ analysis. $\mathrm{LOH}$ was determined using microsatellite markers on 2q32-q33 (D2S389) and 2q33-q36 (D2S128) which were previously described $(23,31)$. Oligonucleotide primer sequences were D2S389 (5'-TAAAGC CTAGTGGAAGATCATC-3', 5'-GCTGAGTTAACAGTTAT CAACAATT-3') and D2S128 (5'-AAACTGAGATTTGTCTA AGGGG-3', 5'-AGCCAGGAATTTTTGCTATT-3'). PCR was performed in $20 \mu \mathrm{l}$ reactions consisting of $200 \mathrm{ng}$ of DNA, 1X PCR buffer, $0.2 \mathrm{mM}$ dNTPs, 10 pmol of each primer, and 1 unit of AmpliTaq Gold DNA polymerase. The condition for amplification was as follows: after denaturation at $95^{\circ} \mathrm{C}$ for $14 \mathrm{~min}$, then denaturation at $95^{\circ} \mathrm{C}$ for $1 \mathrm{~min}$, annealing at $55^{\circ} \mathrm{C}$ for $1 \mathrm{~min}$, and extension at $72^{\circ} \mathrm{C}$ for $1 \mathrm{~min}$ for 35 cycles and final extension at $72^{\circ} \mathrm{C}$ for $10 \mathrm{~min}$. Ten microliters of PCR products was mixed with $10 \mu \mathrm{l}$ of stop solution containing $95 \%$ formamide, $10 \mathrm{mM} \mathrm{NaOH}, 0.25 \%$ bromophenol blue and $0.25 \%$ xylene cyanol FF. The mixture was denatured at $95^{\circ} \mathrm{C}$ for $5 \mathrm{~min}$, put onto ice for $5 \mathrm{~min}$, electrophoresed on $12 \%$ polyacrylamide gels containing 10\% glycerol with $1 \mathrm{X}$ TBE buffer and stained with ethidium bromide. $\mathrm{LOH}$ was defined as reduction of the intensity of the signal of a single allele by $>50 \%$ in the tumor DNA by direct visualization when compared with the corresponding DNA of peripheral blood lymphocytes.

RNA extraction and RT-PCR procedures. Total-RNA was extracted from cultured cells using the RNA-Bee solution kit following the manufacturer's protocol (Tel-Test, Friendswood, TX, USA). Total-RNA was treated with RQ1 RNase-free DNase $(1 \mu \mathrm{l} / \mu \mathrm{g})$ (Promega) at $37^{\circ} \mathrm{C}$ for $30 \mathrm{~min}$ and added $1 \mu \mathrm{l}$ of RQ1 DNase stop solution to terminate the reaction, followed by heat inactivation at $65^{\circ} \mathrm{C}$ for $10 \mathrm{~min}$. The RNA was purified with a phenol/chloroform extraction and precipitated with ethanol. First-strand cDNA synthesis was performed with $2 \mu \mathrm{g}$ of DNasetreated mRNA. The cDNA was made with random hexamers using a reverse transcription system (Promega) according to the manufacturer's protocol. PCR was performed with $2 \mu \mathrm{l}$ cDNA in a $25 \mu \mathrm{l}$ reaction mixture of $1 \mathrm{X}$ PCR buffer, $0.2 \mathrm{mM}$ each dNTP, 10 pmol of each primer inhibin- $\alpha$ (5'-AGGAAGAGGAG GATGTCTCC-3', 5'-GAGTAACCTCCATCCGAGGT-3'; $823 \mathrm{bp}$ ), betaglycan (5'-ACATGGATAAGAAGCGATTC AGC-3', 5'-AACGCAATGCCCATCACGGTTAG-3'; 331 bp), and $\beta$-actin (5'-CTTCTACAATGAGCTGCGTG-3', 5'-TCATG AGGTAGTCAGTCAGG-3'; 305 bp) and 1 unit of AmpliTaq Gold DNA polymerase. The reactions were carried out in a thermal cycler with an initial denaturation step at $95^{\circ} \mathrm{C}$ for $14 \mathrm{~min}$ followed by 35 cycles ( 30 cycles for betaglycan and 22 cycles for $\beta$-actin) of denaturation at $95^{\circ} \mathrm{C}$ for $1 \mathrm{~min}$, primer annealing at $50^{\circ} \mathrm{C}$ (inhibin- $\alpha$ ), $64^{\circ} \mathrm{C}$ (betaglycan), and $55^{\circ} \mathrm{C}(\beta$-actin) for $1 \mathrm{~min}$, and extension at $72^{\circ} \mathrm{C}$ for $1 \mathrm{~min}$. The reaction was terminated at $72^{\circ} \mathrm{C}$ for $10 \mathrm{~min}$ and samples were stored at $4^{\circ} \mathrm{C}$. Ten microliters of PCR products was separated by electrophoresis on a $2 \%$ agarose gel containing ethidium bromide $(0.5 \mu \mathrm{g} / \mathrm{ml})$ and visualized by image analysis.

Immunohistochemical staining for the inhibin- $\alpha$ protein. Monolayer cell lines were seeded in eight-well Lab-Tek II chamber slides with covers (Nalgene, Rochester, NY, USA) and the cells were treated with 5-AzaC. At the end of the treatment period, suspension cell lines were attached on collagen coatedslides by cytospin. After a PBS wash, the cells were fixed on the slides using $-10^{\circ} \mathrm{C}$ methanol for 5 min and air dried. The chambers were taken off before the immunostaining procedure. After incubation with $0.3 \% \mathrm{H}_{2} \mathrm{O}_{2}$ for 10 min to block the endogenous peroxidase, the cells were incubated for $1 \mathrm{~h}$ with human inhibin- $\alpha$ mouse monoclonal antibody diluted to $5 \mu \mathrm{g} / \mathrm{ml}$ (Serotec, Kidlington, England). Subsequently, the biotin-conjugated secondary antibody was incubated for $30 \mathrm{~min}$ using mouse $\mathrm{ABC}$ staining systems according to the manufacturer's protocol (Santa Cruz Biothechnology, Santa Cruz, CA, USA), and incubated with horseradish peroxidase (HRP)-streptavidin complex for $30 \mathrm{~min}$ and visualized by reaction with diaminobenzidine (DAB) for $5 \mathrm{~min}$. Slides were stained with Mayer's haematoxylin and dehydrated through ethanol and xylene. Concentrationmatched mouse $\mathrm{IgG}_{2 \mathrm{a}}$ was used as a negative control.

Flow cytometric analysis. The cultured cells were detached with $0.05 \%$ trypsin-EDTA solution. After washing with cold PBS, cells were then incubated with a 1:50 dilution of anti-inhibin- $\alpha$ goat polyclonal antibody (Santa Cruz Biotechnology) or normal goat serum as a negative control for $30 \mathrm{~min}$ at $4^{\circ} \mathrm{C}$. After being washed three times with cold PBS, cells were stained with fluorescein isothiocyanate (FITC)-labeled donkey antibody to 1:50 diluted rabbit immunoglobulin for $30 \mathrm{~min}$ at $4^{\circ} \mathrm{C}$. Washing was repeated in the same manner and cell surface immunofluorescence was analyzed using a FACSCalibur with CellQuest software (Becton Dickinson, Franklin Lakes, NJ, USA).

5-aza-2'-deoxycytidine (5-AzaC) treatment. Cells were seeded at a density of $5 \times 10^{5}$ cells and then allowed to attach during a 24-h period, and treated with 5-AzaC (Sigma, St. Louis, MO, USA) at $10 \mu \mathrm{M}$ for 5 days, which was consistent with another report (32). For the doubling time experiment, 5-AzaC was used at $5 \mu \mathrm{M}$. The medium and the drug were replaced every 2 day. At the end of the treatment period, the medium was removed and the cell pellets were used for analysis.

Determination of cell doubling time. Cells were treated with 5-AzaC and washed with PBS. Cells were seeded at $2 \times 10^{4}$ cells/ $\mathrm{ml}$ in 12-well plates with culture medium, and cell number/dish was counted with a trypan blue assay each day for 5 consecutive days. Untreated cells were analyzed under similar conditions as a control. The average cell number from two plates was determined, and the mean cell numbers were plotted to define the cell population doubling times. The cell population doubling time was calibrated by a formula of Kuchler (33).

Cell cycle analysis. Cells (5x105/100-mm dish) were treated with 5-AzaC. At the end of the treatment period, cells were harvested and washed with PBS. Cells were fixed with $70 \%$ ethanol for $1 \mathrm{~h}$, treated with RNasin $(20 \mu \mathrm{g} / \mathrm{ml})$ at $37^{\circ} \mathrm{C}$ for $1 \mathrm{~h}$, stained with PI $(50 \mu \mathrm{g} / \mathrm{ml})$ (Sigma). DNA content at each cell cycle stage was analyzed using a FACSCalibur with CellQuest software (Becton Dickinson).

\section{Results}

Methylation status of the inhibin- $\alpha$ gene in human gastric cancer cell lines. Transcriptional silencing of tumor suppressor genes mediated by hypermethylation is a common feature of human cancer $(23,34)$. As well, change in promoter methylation has been 


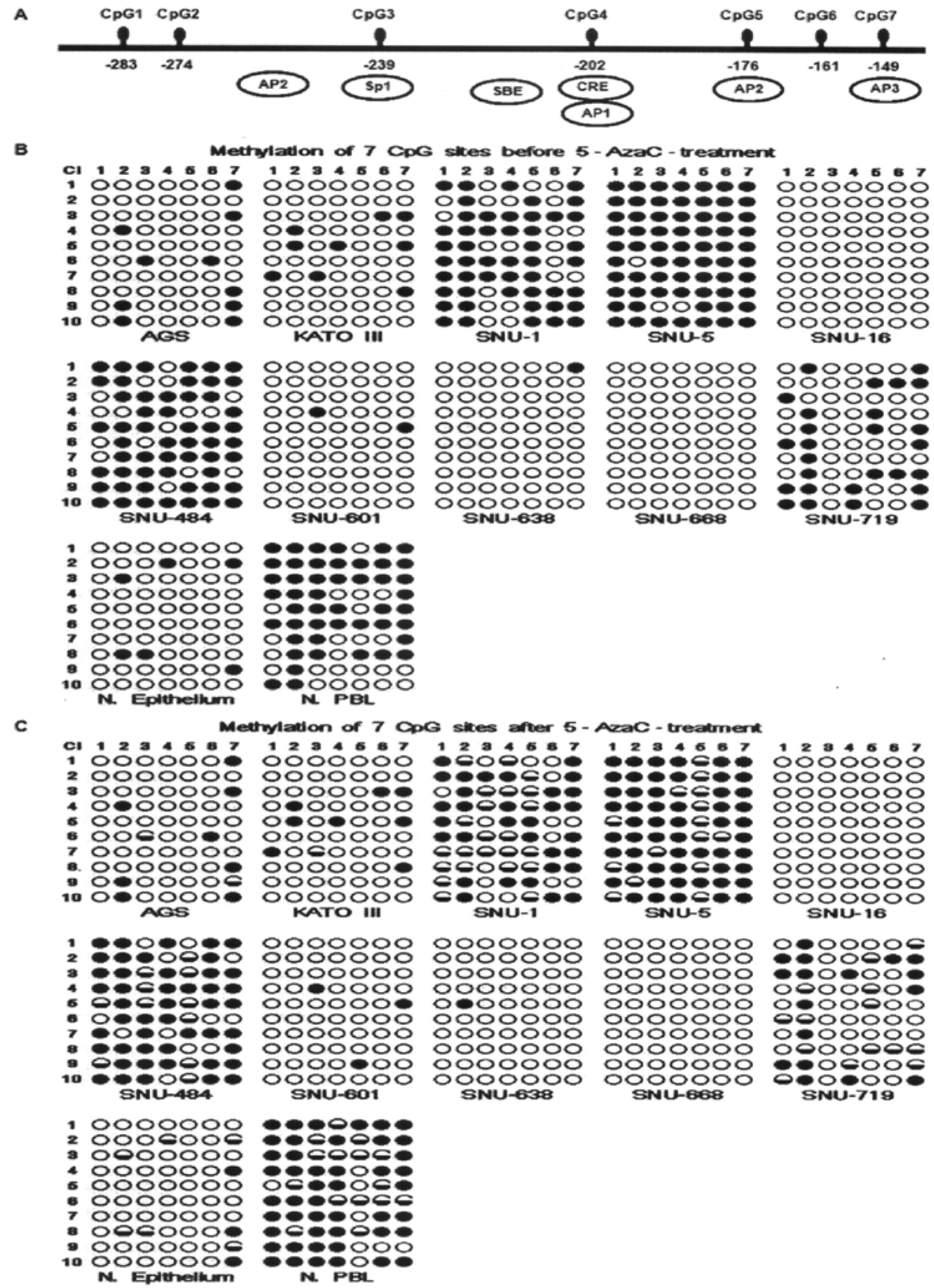

Figure 1. Methylation analysis of the inhibin- $\alpha$ promoter region. (A) Map of the seven CpG sites in the inhibin- $\alpha$ promoter within a 135 bp regions from -149 to -284 of the ATG start. (B) Methylation profile of the inhibin- $\alpha$ promoter region in human gastric cancer cell lines. (C) Methylation profile of the inhibin- $\alpha$ promoter region in human gastric cancer cell lines after 5-AzaC treatment. Cells were exposed to 5-AzaC for 5 days. Methylation levels were determined by sequencing of 10 independent clones derived from amplified bisulfite-treated DNA isolated from cancer cell lines. Methylated and unmethylated CpGs are represented by closed and open circles, respectively. Demethylated CpGs after 5-AzaC treatment are represented by half-closed circles. AP1,2, and 3, activator proteins 1, 2, and 3; CRE, cAMP response element; SP1, specific protein 1, SBE; Smad binding element; N. Epithelium, normal epithelium; N. PBL, normal peripheral blood leukocytes.

reported as a potential regulatory mechanism for the inhibin- $\alpha$ gene in prostate tumors (23). Thus, the methylation state of inhibin- $\alpha$ gene was investigated in human gastric cancer cells. Methylation was determined at the seven $\mathrm{CpG}$ sites which are located -149 to -284 bp from the ATG site of the inhibin- $\alpha$ gene, using bisulfite DNA sequencing (23) (Fig. 1A). We observed that inhibin- $\alpha$ promoter was heavily methylated in the SNU-1, SNU-5, and SNU-484 cell lines. The promoter was moderately methylated in SNU-719, AGS, and KATO III cell lines. In contrast, the promoters were largely unmethylated in the SNU-16, SNU-601, SNU-638 and SNU-668 cell lines. The promoter of inhibin- $\alpha$ in normal epithelium (N. Epithelium) was relatively unmethylated whereas that in normal peripheral blood leukocytes (N. PBL) was heavily methylated (Fig. 1B). To determine how methylation status might affect the growth characteristics of these cells (reported in a later section), the lines were treated with 5-AzaC, a demethylating agent. The result was that many $\mathrm{CpG}$ sites were unmethylated after treatment with 5-AzaC in SNU-1, SNU-5, 


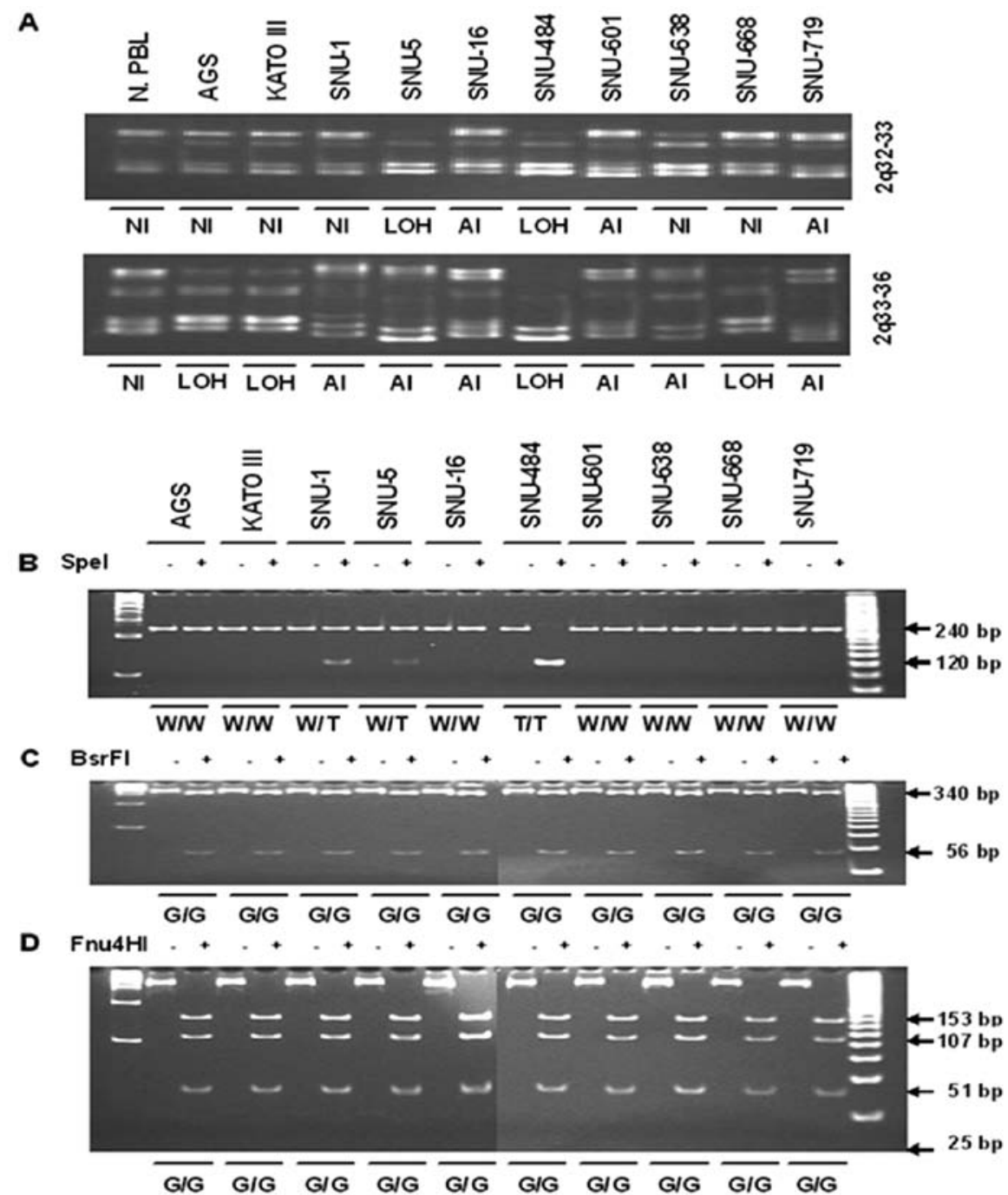

Figure 2. (A) LOH analysis of chromosome $2 q$ and (B-D) mutation analysis at the sites of -16 bp of 5'-UTR and +769 bp of exon 2. (A) Genomic DNAs obtained from human gastric cancer cell lines were amplified using PCR with primers as described in Materials and methods. Primers covered the microsatellite markers on 2q32-q33 and 2q33-q36. PCR product was separated on 12\% polyacrylamide gels, stained with ethidium bromide, and visualized by image analysis. LOH was expressed when band intensity was decreased below 50\% compared with normal band. AI was expressed when band size was different from normal allele. NI, not informative; LOH, loss of heterozygosity; AI, allelic imbalance. (B) Fragment A (240 bp) which contained region of -16 bp of 5'-UTR was digested with SpeI after PCR as described in Materials and methods. Fragment of $240 \mathrm{bp}$ indicated a wild-type allele, whereas two fragments of 120 bp corresponded to an allele which contains T at -16 bp of 5'-UTR. (C) Fragment B (396 bp) which contained region of 769G $>$ A of exon 2 digested with BsrFI after PCR as described in Materials and methods. PCR product rendered two fragments of 340 and $56 \mathrm{bp}$ in wild-type allele $\mathrm{G}$ and remained intact in the mutated allele A which was not observed. (D) Fragment B was digested with Fnu4HI. PCR product rendered four fragments of 153, 107, 51 and 25 bp in the wild-type allele, whereas the allele with substituted $769 \mathrm{G}>\mathrm{A}$ rendered four fragments of $153,107,76$ and $51 \mathrm{bp}$. The result of (C) and (D) revealed that substituted $769 \mathrm{G}>\mathrm{A}$ of exon 2 was not occurred in the human gastric cancer cell lines. PCR product incubated with restriction enzyme overnight and separated on 8 and $15 \%$ polyacrylamide gels, stained with ethidium bromide, and visualized by image analysis. $+\mathrm{E}$, with restriction enzyme; $-\mathrm{E}$, without restriction enzyme.

SNU-484 and SNU-719 although the degree of methylation loss was different for each line. Of interest was that specifically $\mathrm{CpG}$ 5 site was strongly influenced by 5 -AzaC (Fig. 1C).

LOH and mutation of the inhibin- $\alpha$ gene in human gastric cancer cell lines. Transcriptional silencing of tumor suppressor genes can also occur through $\mathrm{LOH}$ of the gene $(23,35)$. Thus, we investigated the LOH of inhibin- $\alpha$ gene in human gastric cancer cells. Microsatellite markers on 2q32-q33 (D2S389) and 2q33-q36 (D2S128) was amplified by PCR. The result was that $\mathrm{LOH}$ occurred with at least one microsatellite marker at 2q32-33 in SNU-5 and SNU-484 whereas LOH at 2q33-36 was observed in AGS, KATO III and SNU-484. Interestingly, LOH both at 2q32-33 and 2q33-36 was observed in SNU-484.
In addition, allelic imbalances were observed both at 2q32-33 locus in SNU-16, SNU-601, and SNU-719 and at 2q33-36 locus in SNU-1, SNU-5, SNU-16, SNU-601, SNU-638, and SNU-719 (Fig. 2A).

Transcriptional silencing of tumor suppressor genes can also occur through mutation of the gene. Two polymorphic sites were indentified in the inhibin- $\alpha$ gene: $-16 \mathrm{C}>\mathrm{T}$ in the 5'-UTR (30) and $769 \mathrm{G}>\mathrm{A}$ in exon 2 in previous report $(11,30,36)$. Thus, we investigated these variants of the inhibin- $\alpha$ gene in human gastric cancer cells. The first investigated region was located at the 5'-UTR region (Fig. 2B). The second investigated region was located at 769 bp within exon 2 region (Fig. 2C and D). Thus, the single base change at $769 \mathrm{G}>\mathrm{A}$ of exon 2 was not found in all human gastric cancer cell lines. 


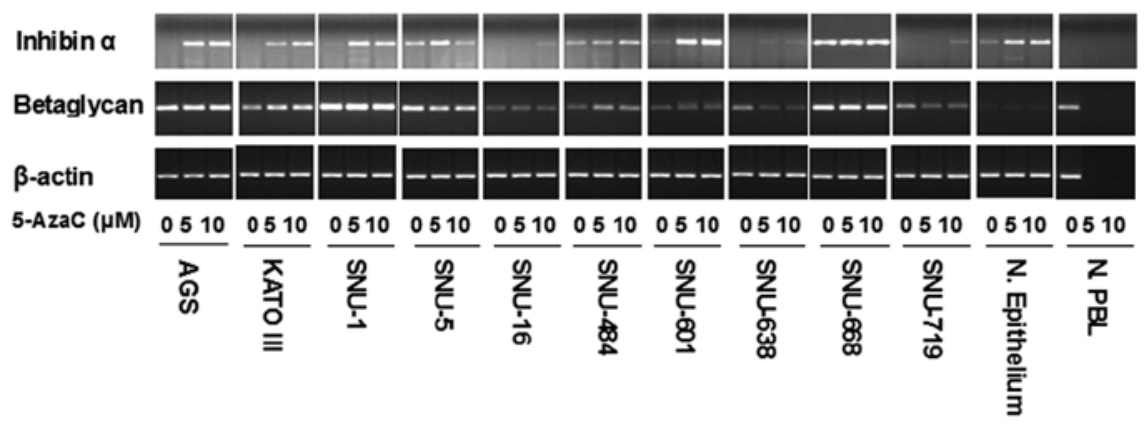

Figure 3. mRNA levels of inhibin- $\alpha$ and betaglycan after 5-AzaC treatment. Cells were cultured with 5-AzaC. Then mRNA was extracted and RT-PCR was performed. PCR product was separated on a $\%$ agarose gel, stained with ethidium bromide and visualized by image analysis. The mRNA of $\beta$-actin was amplified as a control.

A

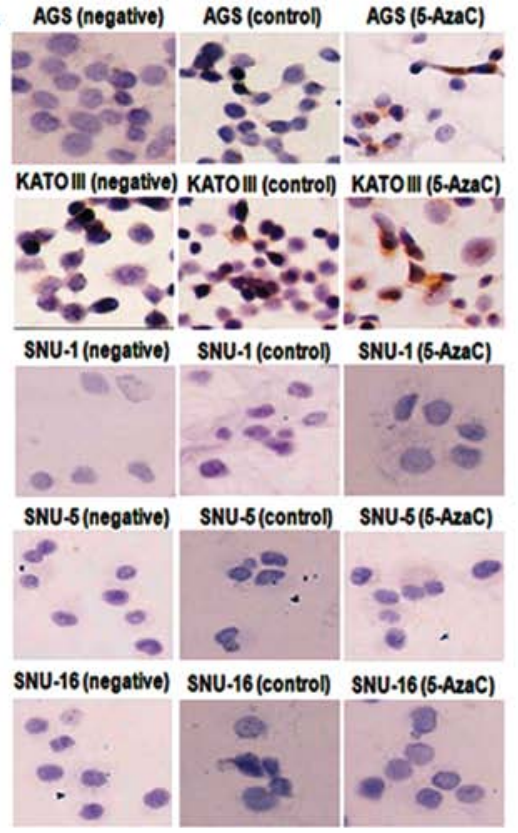

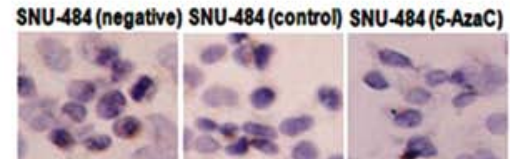

SNU-601 (negative) SNU-601 (control) SNU-601 (5-A2aC)
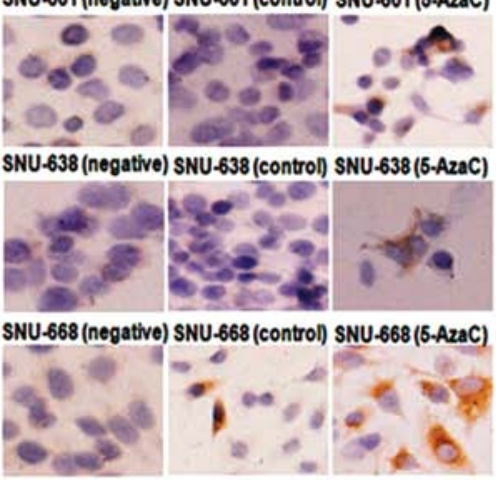

SNU.719 (negative) SNU-719 (control) SNU.719 (5-AzaC)

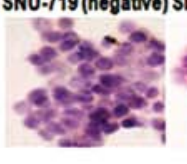

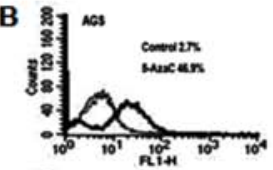
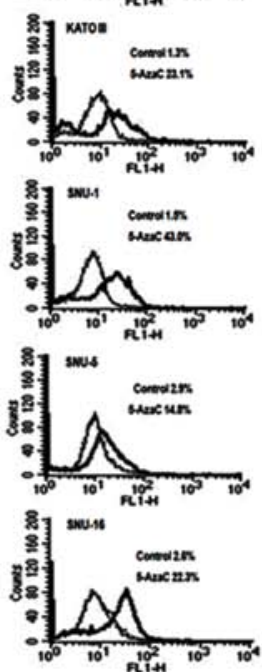
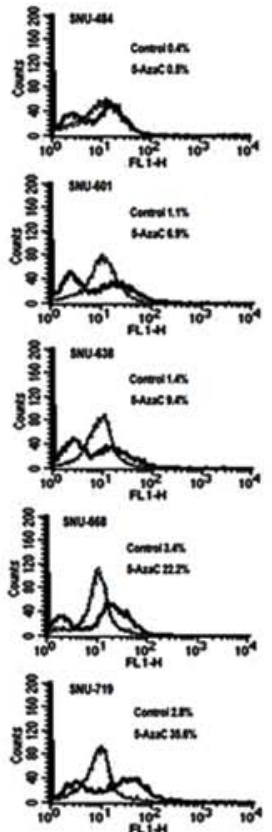

Figure 4. Inhibin- $\alpha$ protein detected by (A) immunohistochemistry and (B) flow cytometry. (A) For monolayer cells, cells were culture in chambered slide with 5-AzaC. For suspension cells, cells were cultured with 5-AzaC, washed with PBS and attached on collagen coated-slides by cytospin. The imunoreactivity of inhibin- $\alpha$ protein was detected using inhibin- $\alpha$ monoclonal antibody. Immunostained cells were examined under $\mathrm{x} 200$ magnifications using a light microscope. (B) Cells were cultured with 5-AzaC. These cells were incubated with anti-inhibin- $\alpha$ polyclonal antibody and FITC conjugated antibody. Diluted normal goat serum was used as a negative control for the primary antibody. Then inhibin- $\alpha$ protein was detected by flow cytometry. 5 -AzaC-treated cells, thick line; control cells, thin line.

The low levels of $m R N A$ and protein of inhibin- $\alpha$ in human gastric cancer cell lines. To determine how the observed differences in promoter DNA methylation or LOH might relate to differences in inhibin- $\alpha$ gene expression among cell lines, we measured inhibin- $\alpha$ mRNA levels by PCR, and observed low or undetectable levels of mRNA in all gastric cancer cell lines except in SNU-668. In most lines, the low level of mRNA was increased following 5-AzaC treatment (Fig. 3). Recently, inhibin- $\alpha$ was shown to act through a betaglycan signaling system (28). When we measured the level of mRNA of betaglycan, it was not closely associated with the mRNA level of inhibin- $\alpha$. Moreover, mRNA level of betaglycan was not changed with 5-AzaC treatment in contrast to inhibin- $\alpha$ (Fig. 3).
The low level of mRNA of inhibin- $\alpha$ in most cell lines is expected to result in low levels of inhibin- $\alpha$ protein. When we measured the inhibin- $\alpha$ protein by IHC using a monoclonal inhibin- $\alpha$ antibody, faint signals which meant very low level of inhibin- $\alpha$ was observed in all human gastric cell lines. The low level of inhibin- $\alpha$ could be increased with 5-AzaC treatment at detectable levels in AGS, SNU-601, SNU-638, SNU-668 and SNU-719 (monolayer cell lines) and KATO III (suspension cell line). Other suspension cell line such as SNU-1, SNU-5 and SNU-16 were not immunostained both on collagen-coated slide and poly-D-lysine coated slide, resulting in no signals (Fig. 4A). The protein profile was reinvestigated using flow cytometry. When we measured 

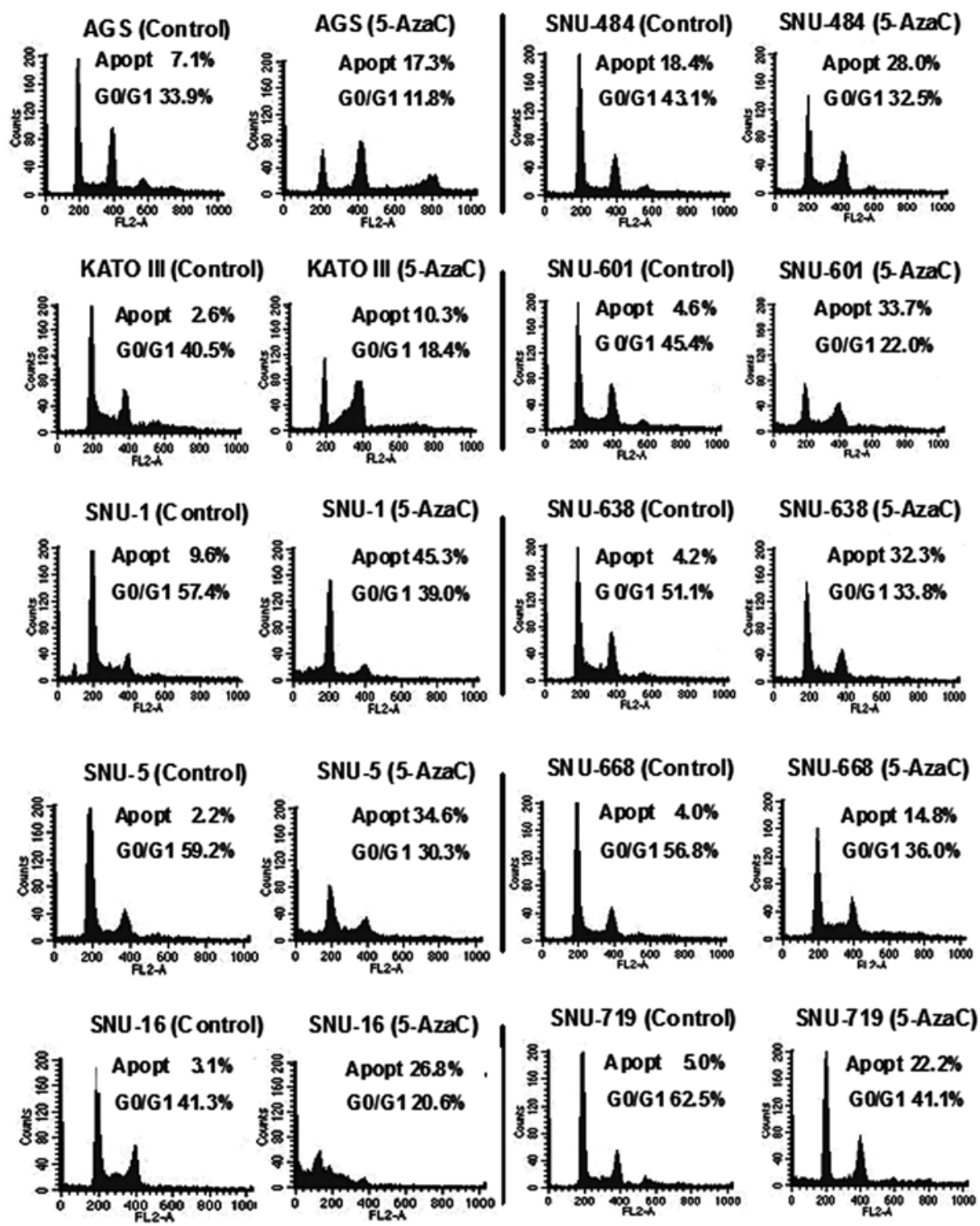

Figure 5. Apoptosis and cell cycle after 5-AzaC treatment. Cells were cultured with 5-AzaC. Cells were fixed in 70\% ethanol after media were removed. Cells were then washed with PBS, treated with RNasin, and stained PI. DNA content at each cell cycle stage was analyzed by flow cytometry. The percentage of cells in apoptosis and G0/G1 phase were calculated.

inhibin- $\alpha$ at 5 days after 5 -AzaC treatment, the levels of inhibin- $\alpha$ protein were increased between 1.25 and 28.67-fold compared with control among the various cell lines (Table II). Fluorescence intensities after 5-AzaC treatment were particularly higher in AGS, KATO III, SNU-1, SNU-16, SNU-668 and SNU-719 compared to control (Fig. 4B).

Cell growth suppression and apoptosis induced by 5-AzaC. Low levels of inhibin- $\alpha$ were expected in cells undergoing rapid division since inhibin- $\alpha$ is known as a tumor suppressor. Reactivation of the inhibin- $\alpha$ gene was observed after 5-AzaC treatment, so we sought to determine if this altered the growth characteristics of the cells. When we measured cell viability after 5-AzaC treatment $(5 \mu \mathrm{M})$ it was decreased between $47.6 \%$ in SNU-5 and 35.6\% in SNU-638 (Table I). When we measured the doubling time after 5-AzaC treatment it was increased 1.24 (SNU-484) to 2.56-fold (SNU-16) (Table I). Related to the low cell viability, apoptosis was also investi- gated. When we analyzed cancer cells using flow cytometry, apoptosis was increased 1.52 to 15.73 -fold in human gastric cancer cells after 5-AzaC treatment. In addition, the G0/G1 phase was decreased from 0.34 (AGS) to 0.75 -fold (SNU-484) (Fig. 5, Table II).

When the cells undergoing apoptosis and cell cycle changes were investigated by microscopy, morphological changes were observed in epithelial-like cells (AGS, SNU-484, SNU-601, SNU-638, SNU-668 and SNU-719) and spherical cells (KATO III) after 5-AzaC treatment. Minor morphological changes were observed in lymphoblast-like cells (SNU-1, SNU-5 and SNU-16) (Fig. 6).

\section{Discussion}

Numerous reports link the inhibin- $\alpha$ gene with cancer since it was initially identified as a tumor suppressor gene in the gonads and adrenals by functional studies using inhibin- $\alpha$ deficient 
Table I. Effects of 5-AzaC on growth suppression.

\begin{tabular}{|c|c|c|c|c|c|c|}
\hline \multirow[b]{2}{*}{ Gastric cancer cell lines } & \multicolumn{3}{|c|}{$\begin{array}{c}\text { Viability (\%) } \\
\text { 5-AzaC }\end{array}$} & \multicolumn{2}{|c|}{$\begin{array}{l}\text { Doubling time }(\mathrm{h}) \\
\text { 5-AzaC }\end{array}$} & \multirow[t]{2}{*}{ Growth suppression (fold) } \\
\hline & $0 \mu \mathrm{M}$ & $5 \mu \mathrm{M}$ & $10 \mu \mathrm{M}$ & $0 \mu \mathrm{M}$ & $5 \mu \mathrm{M}$ & \\
\hline AGS & 100 & 34.4 & 33.9 & 20 & 50 & 2.50 \\
\hline KATO III & 100 & 39.4 & 38.9 & 36 & 68 & 1.89 \\
\hline SNU-1 & 100 & 41.0 & 30.7 & 26 & 57 & 2.19 \\
\hline SNU-5 & 100 & 47.6 & 22.2 & 34 & 55 & 1.62 \\
\hline SNU-16 & 100 & 45.5 & 25.4 & 27 & 69 & 2.56 \\
\hline SNU-484 & 100 & 47.4 & 27.4 & 67 & 83 & 1.24 \\
\hline SNU-601 & 100 & 37.0 & 26.0 & 47 & 84 & 1.79 \\
\hline SNU-638 & 100 & 35.6 & 28.8 & 58 & 82 & 1.41 \\
\hline SNU-668 & 100 & 46.1 & 32.7 & 74 & 135 & 1.82 \\
\hline SNU-719 & 100 & 46.0 & 23.3 & 184 & 412 & 2.24 \\
\hline
\end{tabular}

Cells $\left(5 \times 10^{5} / 100-\mathrm{mm}\right.$ dish) were treated with 5 -AzaC for 5 days and then changed with fresh medium and drug every 2 days. Viable cells were counted by the trypan blue assay. At the end of the treatment period, the cells were seeded in 12 -well plate at $2 \times 10^{4}$ cells $/ \mathrm{ml}$. Cell number/plates was counted by trypan blue assay each day for 5 consecutive days. Untreated cells were analyzed under similar condition as a control. The average cell number from two plates was determined, and the mean cell numbers were plotted to define the cell population doubling times.

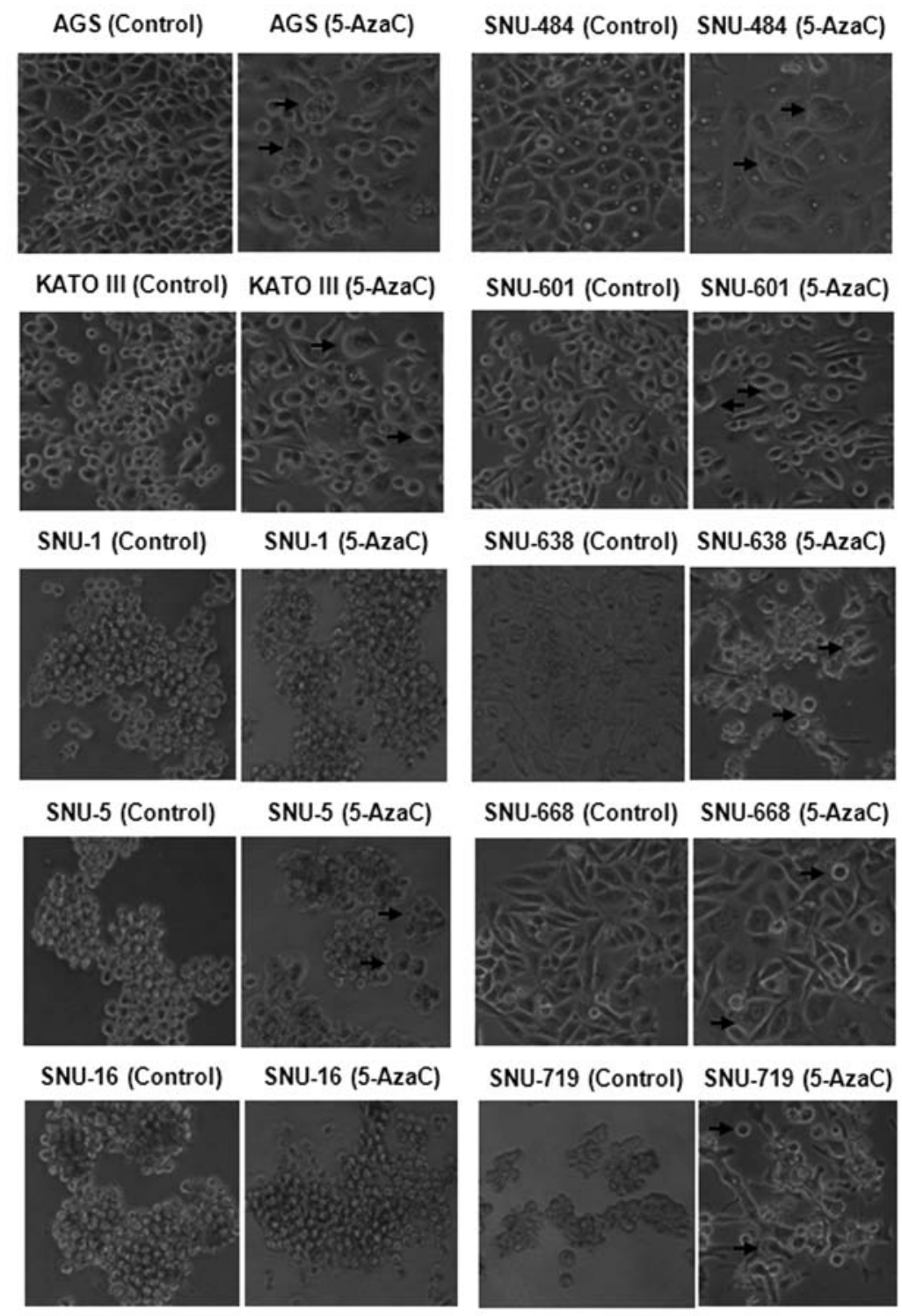

Figure 6. Morphology of cells after 5-AzaC treatment. Cells were cultured with 5-AzaC and examined under x200 magnifications using light microscopy. 


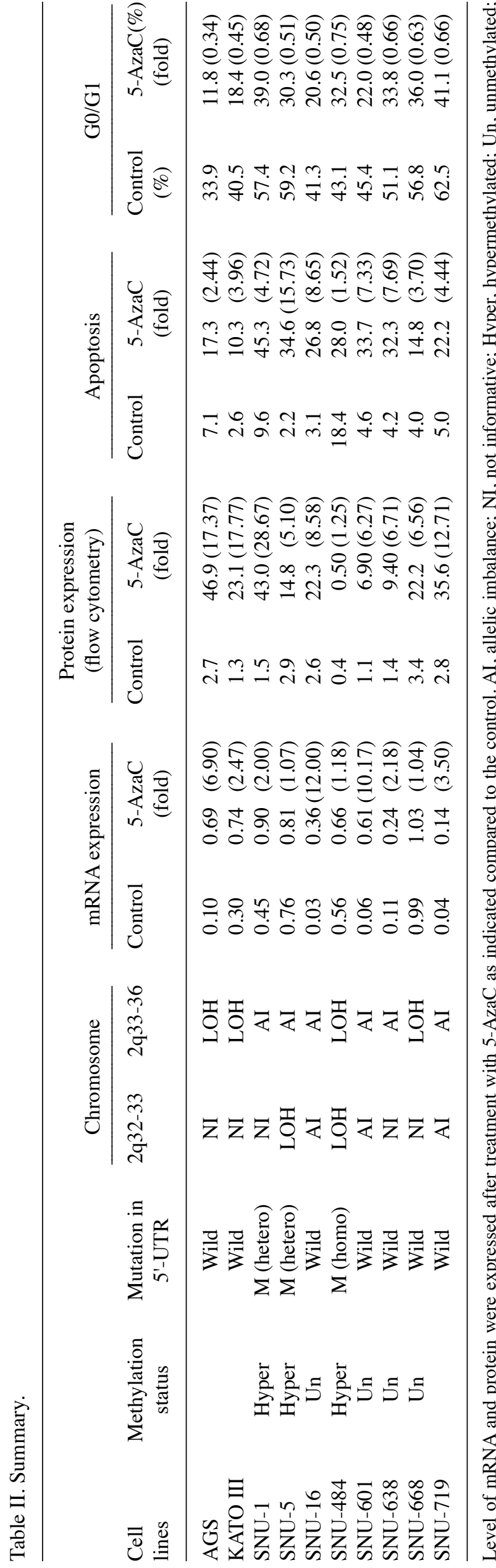

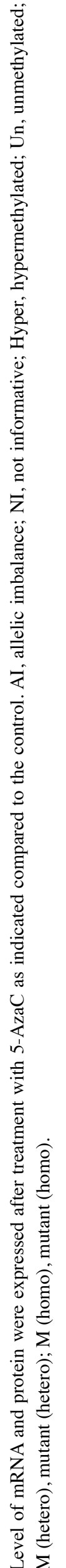

mice (20-22). Roles for inhibin- $\alpha$ in cell growth have been proposed in prostate, endometrium, and breast, with loss of inhibin expression or sensitivity linked to tumor initiation and progression and to poor patient survival (37). Although it was suggested that inhibin- $\alpha$ acts as a tumor suppressor during early tumorigenesis, it might also act as a tumor promoter during late-stage disease in prostate cancer $(24,25)$.

Hypermethylation, $\mathrm{LOH}$, and polymorphisms of inhibin- $\alpha$ were investigated in this study. Hypermethylation of the inhibin- $\alpha$ gene promoter was observed in several human gastric cancer cell lines although the degree of methylation varied substantially among cell lines. Heavy methylation was found in SNU-1, SNU-5 and SNU-484 whereas moderate methylation was observed in SNU-719, AGS and KATO III. Little or no methylation was observed in SNU-16, SNU-601, SNU-638 and SNU-668. Demethylation colud be induced by 5 -AzaC in heavily or moderately methylated $\mathrm{CpG}$ sites in SNU-1, SNU-5, SNU-484 and SNU-719. In these cells, all $\mathrm{CpG}$ sites were influenced by $5-\mathrm{AzaC}$, but $\mathrm{CpG} 5$ was more strongly influenced by 5-AzaC than other sites (Fig. 1). Previously, it was reported that the inhibin- $\alpha$ gene promoter was hypermethylated in prostate cancer (23). In this report, four $\mathrm{CpG}$ sites (CpG1, CpG2, CpG5 and CpG6) were unique in human whereas three $\mathrm{CpG}$ sites (CpG3, $\mathrm{CpG} 4$ and $\mathrm{CpG} 7)$ were conserved between species. CpG5 differed from the bovine, rat, and mouse sequence (23). Of interest is that this site that varies among species corresponds to the site that is strongly influenced by 5 -AzaC.

$\mathrm{LOH}$ of the inhibin- $\alpha$ gene locus was also investigated. Initially, $\mathrm{LOH}$ was observed in inactivation of tumor suppressor genes (23). In this study, $\mathrm{LOH}$ at $2 \mathrm{q} 32-33$ was observed in SNU-5 and SNU-484 whereas LOH at 2q33-36 was observed in AGS, KATO III and SNU-484 (Fig. 2A). $\mathrm{LOH}$ at 2q32-36 contains the chromosome region harboring the inhibin- $\alpha$ gene (38). LOH at the inhibin- $\alpha$ locus on chromosome $2 \mathrm{q}$ was also reported in $6 \%$ granulosa cell tumors (35) and in $42 \%$ of prostate carcinomas (23).

Mutation of the inhibin- $\alpha$ gene was investigated. Mutation at -16 bp site of the 5'-UTR was observed in SNU-1 (one allele), SNU-5 (one allele) and SNU-484 (both alleles). However, mutation at 769 bp site within exon 2 region was not observed (Fig. 2B-D). Although controversy exists, mutation at -16 , and 769 of the inhibin- $\alpha$ gene has been related to premature ovarian failure (POF) $(11,30,36)$. The observed DNA changes directly influences the inhibin- $\alpha$ mRNA levels. In our study, it was observed that all human gastric cancer cell lines had at least one of the discussed DNA alterations including methylation, allelic imbalance including $\mathrm{LOH}$, and nucleotide mutation, and these lines all exhibit low inhibin- $\alpha$ expression.

It was reported that levels of mRNA and protein of tumor suppressor gene were very low in cancer cells $(24,39)$. In this study, low level of inhibin- $\alpha$ gene transcript existed in human gastric cancer cell lines except SNU-668 (Fig. 3). Parallel with this, low level of inhibin- $\alpha$ protein was observed in most of cell lines (Fig. 4A and B). Consistent with this, it was reported that malignant tissues lacked inhibin- $\alpha$ gene transcripts and protein whereas non-malignant regions of human primary prostate carcinomas expressed inhibin- $\alpha$ (24). These low levels of mRNA and protein inhibin- $\alpha$ could be 
increased to some degree with 5-AzaC treatment, consistent with the view that hypermethylation contributes to suppression of inhibin- $\alpha$ expression. These low levels of $m R N A$ and protein of inhibin- $\alpha$ seemed to be correlated with the cancer state, whereas there was no such correlation to betaglycan mRNA levels. The levels of betaglycan mRNA were not changed after treatment of 5-AzaC (Fig. 3).

5-AzaC treatment enhanced apoptosis 1.52 to 15.73 -fold compared to the controls (Fig. 5, Table II) and 5-AzaC suppressed cell growth by increasing the doubling time 1.24 to 2.56-fold (Table I). Morphology of the cells was changed after 5-AzaC treatment as presented in Fig. 6. The cell can be influenced by inhibin- $\alpha$ induced by $5-\mathrm{AzaC}$ or $5-\mathrm{AzaC}$ itself. It was reported that inhibin- $\alpha$ influences cell proliferation, cell growth, and metastasis $(25,40,41)$. In normal cells, it was reported that inhibin A increased apoptosis in early ovarian antral follicles (40). It was also reported that overexpressed inhibin- $\alpha$ (1-32 amino acid) fragment inhibited bovine granulose cell (GC) proliferation and induced apoptosis in GC (42). Inhibin- $\alpha$ decreased the proliferation of ovarian cancer cell lines such as SKOV3, OCC1, OVCAR3 and A2780-s (41). Inhibin- $\alpha$ reduced tumor growth in $\mathrm{LNCaP}$ which is androgen-dependent prostate cancer (PCa) whereas inhibin- $\alpha$ increased tumor growth and metastasis in PC3 which is androgen-independent PCa (25). Importantly, targeted disruption of the inhibin- $\alpha$ gene resulted in an ovarian phenotype of granulosa cell tumors $(20,43)$. Combined with our results and previous reports $(20,43)$, it is evident that inhibin- $\alpha$ must be maintained at low levels in many cancerous cell types. These results suggest that inhibin- $\alpha$ has a critical function at the cellular level. 5-AzaC itself is known to have a cytotoxic effect. However, it was reported that this occurs through DNA methyltransferase (Dnmt) 3a, Dnmt3b (44) and caspase-8 (45). Moreover, it was reported that 5-AzaC altered the expression of several proteins involved in cell cycle regulation, apoptosis, and survival $(32,46)$. In our study, it seemed that 5-AzaC influenced the cell through inhibin- $\alpha$ induction as well as other known gene induction.

As to the mechanism of action of inhibin- $\alpha$ in the process of carcinogenesis, there is little data and much to be learned. Carcinogenesis is a complex process whereby malignant transformation occurs through a sequence of events. The hallmarks of cancer include sustaining proliferation, evading growth suppressors, resisting cell death, enabling replicative immortality, inducing angiogenesis, and activating invasion and metastasis. Underlying these hallmarks are genome instability and inflammation (47). Our result suggested that inhibin- $\alpha$ acts at steps including sustaining proliferation, evading growth suppressors, and altering cell death. Among these steps, apoptosis has been relatively well studied. In cancer cells, inhibin- $\alpha$ is maintained at low level and there is little apoptosis to maintain cancer state. If we limit the function of inhibin- $\alpha$ within apoptosis, two routes are possible. One possibility is that inhibin- $\alpha$ itself reduce apoptosis. Another possible is that inhibin- $\alpha$ reduce apoptosis through inhibin A. In both cases, however, inhibin- $\alpha$ or inhibin A seem to act without changeing betaglycan levels since there was no change in betaglycan mRNA level after 5-AzaC treatment (Fig. 3).

\section{Acknowledgements}

We thank Professor Kelly E. Mayo (Northwestern University) for helpful suggestion and discussion. This study was supported by the Research Fund, 2010 of The Catholic University of Korea.

\section{References}

1. Ying SY: Inhibins and activins: chemical properties and biological activity. Proc Soc Exp Biol Med 186: 253-264, 1987.

2. Ying SY: Inhibins, activins, follistatins: gonadal proteins modulating the secretion of follicle-stimulating hormone. Endocr Rev 9: 267-293, 1988.

3. Robertson DM, Giacometti M, Foulds LM, Lahnstein J, Goss NH, Hearn MTW and de Kretser DM: Isolation of inhibin $\alpha$-subunit precursor proteins from bovine follicular fluid. Endocrinology 125: 2141-2149, 1989.

4. Hotten $\mathrm{G}$, Neidhardt $\mathrm{H}$, Schneider $\mathrm{C}$ and Pohl J: Cloning of a new member of the TGF- $\beta$ family: a putative new activin $\beta_{C}$ chain. Biochem Biophys Res Commun 206: 608-613, 1995.

5. Oda S, Nishimatsu S, Murakami K and Ueno N: Molecular cloning and functional analysis of a new activin $\beta$ subunit: a dorsal mesoderm-inducing activity in Xenopus. Biochem Biophys Res Commun 210: 581-588, 1995.

6. Fang J, Yin W, Smiley E, Wang SQ and Bonadio J: Molecular cloning of the mouse activin $\beta_{\mathrm{E}}$ subunit gene. Biochem Biophys Res Commun 228: 669-674, 1996.

7. de Kretser DM, Hedger MP, Loveland KL and Phillips DJ: Inhibins, activins and follistatin in reproduction. Hum Reprod Update 8: 529-541, 2002.

8. Findlay JK, Drummond AE, Dyson ML, Baillie AJ, Robertson DM and Ethier JF: Recruitment and development of the follicle; the roles of the transforming growth factor- $\beta$ superfamily. Mol Cell Endocrinol 191: 35-43, 2002.

9. Juengel JL and McNatty KP: The role of proteins of the transforming growth factor- $\beta$ superfamily in the intraovarian regulation of follicular development. Hum Reprod Update 11: 144-161, 2005.

10. Knight PG and Glister C: TGF- $\beta$ superfamily members and ovarian follicle development. Reproduction 132: 191-206, 2006.

11. Chand AL, Ooi GT, Harrison CA, Shelling AN and Robertson DM: Functional analysis of the human inhibin $\alpha$ subunit variant $\mathrm{A} 257 \mathrm{~T}$ and its potential role in premature ovarian failure. Hum Reprod 22: 3241-3248, 2007.

12. Welt CK, Taylor AE, Fox J, Messerlian GM, Adams JM and Schneyer AL: Follicular arrest in polycystic ovary syndrome is associated with deficient inhibin A and B biosynthesis. J Clin Endocrinol Metab 90: 5582-5587, 2005.

13. Hamar BD, Buhimschi IA, Sfakianaki AK, Pettker CM, Magloire LK, Funai EF, Copel JA and Buhimschi CS: Serum and urine inhibin $\mathrm{A}$ but not free activin $\mathrm{A}$ are endocrine biomarkers of severe pre-eclampsia. Am J Obstet Gynecol 195: 1636-1645, 2006.

14. Tsigkou A, Marrelli D, Reis FM, et al: Total inhibin is a potential serum marker for epithelial ovarian cancer. J Clin Endocrinol Metab 92: 2526-2531, 2007.

15. Tsigkou A, Luisi S, Reis FM and Petraglia F: Inhibins as diagnostic markers in human reproduction. Adv Clin Chem 45: $1-29,2008$.

16. Cho BN, McMullen ML, Pei L, Yates CJ and Mayo KE: Reproductive deficiencies in transgenic mice expressing the rat inhibin $\alpha$-subunit gene. Endocrinology 142: 4994-5004, 2001.

17. Ahn JM, Jung HK, Cho C, Choi D, Mayo KE, and Cho BN: Changes in the reproductive functions of mice due to injection of a plasmid expressing an inhibin $\alpha$-subunit into muscle: a transient transgenic model. Mol Cell 18: 79-86, 2004.

18. Luisi S, Florio P, Reis FM and Petraglia F: Inhibins in female and male reproductive physiology: role in gametogenesis, conception, implantation and early pregnancy. Hum Reprod Update 11: 123-135, 2005.

19. Risbridger GP, Schmitt JF and Robertson DM: Activins and inhibins in endocrine and other tumors. Endocr Rev 22: 836-858, 2001.

20. Matzuk MM, Finegold MJ, Su JG, Hsueh AJ and Bradley A: $\alpha$-inhibin is a tumour-suppressor gene with gonadal specificity in mice. Nature 360: 313-319, 1992. 
21. Matzuk MM and Bradley A: Identification and analysis of tumor suppressor genes using transgenic mouse models. Semin Cancer Biol 5: 37-45, 1994.

22. Matzuk MM, Finegold MJ, Mather JP, Krummen L, Lu H and Bradley A: Development of cancer cachexia-like syndrome and adrenal tumors in inhibin-deficient mice. Proc Natl Acad Sci USA 91: 8817-8821, 1994.

23. Schmitt JF, Millar DS, Pedersen JS, et al: Hypermethylation of the inhibin $\alpha$-subunit gene in prostate carcinoma. Mol Endocrinol 16: 213-220, 2002

24. Balanathan P, Ball EMA, Wang H, Harris SE, Shelling AN and Risbridger GP: Epigenetic regulation of inhibin $\alpha$-subunit gene in prostate cancer cell lines. J Mol Endocrinol 32: 55-67, 2004

25. Balanathan P, Williams ED, Wang H, et al: Elevated level of inhibin- $\alpha$ subunit is pro-tumourigenic and pro-metastatic and associated with extracapsular spread in advanced prostate cancer. Br J Cancer 100: 1784-1793, 2009.

26. Imai K, Khandoker MAM, Yonai M, et al: Matrix metalloproteinases-2 and -9 activities in bovine follicular fluid of different-sized follicles: relationship to intra-follicular inhibin and steroid concentrations. Domest Anim Endocrinol 24: 171-183, 2003.

27. Jones RL, Findlay JK, Farnworth PG, Robertson DM, Wallace E, and Salamonsen LA: Activin A and inhibin A differentially regulate human uterine matrix metalloproteinases: potential interactions during decidualization and trophoblast invasion. Endocrinology 147: 724-732, 2006.

28. Hempel N, How T, Dong M, Murphy SK, Fields TA and Blobe GC: Loss of betaglycan expression in ovarian cancer: role in motility and invasion. Cancer Res 67: 5231-5238, 2007.

29. Clark SJ, Harrison J, Paul CL and Frommer M: High sensitivity mapping of methylated cytosines. Nucleic Acids Res 22: 2990-2997, 1994.

30. Sundblad V, Chiauzzi VA, Andreone L, Campo S, Charreau EH and Dain L: Controversial role of inhibin $\alpha$-subunit gene in the aetiology of premature ovarian failure. Hum Reprod 21: 1154-1160, 2006.

31. Jones PA and Baylin SB: 2002 The fundamental role of epigenetic events in cancer. Nat Rev Genet 3: 415-428, 2002.

32. Song SH, Jong HS, Choi HH, Inoue H, Tanabe T, Kim NK, and Bang YJ: Transcriptional silencing of cyclooxygenase-2 by hyper-methylation of the $5^{\prime} \mathrm{CpG}$ island in human gastric carcinoma cells. Cancer Res 61: 4628-4635, 2001.

33. Kuchler RJ: Development of animal cell populations in vitro. In: Biochemical Methods in Cell Culture and Virology. Kuchler RJ (ed). Dowden, Hutchinson and Ross Inc. Press, Stroudsburg, PA, pp90-113, 1977.

34. Garinis GA, Patrinos GP, Spanakis NE and Menounos PG: DNA hypermethylation: when tumour suppressor genes go silent. Hum Genet 111: 115-127, 2002.
35. Watson RH, Roy WJ, Davis M, Hitchcock A and Campbell IG: Loss of heterozygosity at the $\alpha$-inhibin locus on chromosome $2 q$ is not a feature of human granulosa cell tumors. Gynecol Oncol 65: 387-390, 1997.

36. Marozzi A, Porta C, Vegetti W, Crosignani PG, Tibiletti MG, Dalpra L and Ginelli E: Mutation analysis of the inhibin alpha gene in a cohort of Italian women affected by ovarian failure. Hum Reprod 17: 1741-1745, 2002.

37. Stenvers KL and Findlay JK: Inhibins: from reproductive hormones to tumor suppressors. Trends Endocrinol Metab 21: 174-180, 2010.

38. Barton DE, Yang-Feng TL, Mason AJ, Seeburg PH and Francke U: Mapping of genes for inhibin subunits $\alpha, \beta_{A}$, and $\beta_{\mathrm{B}}$ on human and mouse chromosomes and studies of jsd mice. Genomics 5: 91-99, 1898

39. Mellor SL, Richards MG, Pedersen JS, Robertson DM and Risbridger GP: Loss of the expression and localization of inhibin $\alpha$-subunit in high grade prostate cancer. J Clin Endocrinol Metab 83: 969-975, 1998

40. Vitale AM, Gonzalez OM, Parborell F, Irusta G, Campo S and Tesone M: Inhibin A increases apoptosis in early ovarian antral follicles of diethylstilbestrol-treated rats. Biol Reprod 67: 1989-1995, 2002.

41. Steller MD, Shaw TJ, Vanderhyden BC and Ethier JF: Inhibin resistance is associated with aggressive tumorigenicity of ovarian cancer cells. Mol Cancer Res 3: 50-61, 2005.

42. Geng LY, Fang M, Yi JM, Jiang F, Moeen-ud-Din M and Yang LG: Effect of overexpression of inhibin $\alpha$ (1-32) fragment on bovine granulosa cell proliferation, apoptosis, steroidogenesis, and development of co-cultured oocytes. Theriogenology 70: $35-43,2008$

43. Myers M, Middlebrook BS, Matzuk MM and Pangas SA: Loss of inhibin alpha uncouples oocyte-granulosa cell dynamics and disrupts postnatal folliculogenesis. Dev Biol 334: 458-467, 2009.

44. Oka M, Meacham AM, Hamazaki T, Rodić N, Chang LJ and Terada N: De novo DNA methyltransferases Dnmt3a and Dnmt3b primarily mediate the cytotoxic effect of 5-aza-2'-deoxycytidine. Oncogene 24: 3091-3099, 2005.

45. Fulda $S$ and Debatin KM: 5-Aza-2'-deoxycytidine and IFN- $\gamma$ cooperate to sensitize for TRAIL-induced apoptosis by upregulating caspase-8. Oncogene 25: 5125-5133, 2006.

46. Valdez BC, Li Y, Murray D, Corn P, Champlin RE and Andersson BS: 5-Aza-2'-deoxycytidine sensitizes busulfanresistant myeloid leukemia cells by regulating expression of genes involved in cell cycle checkpoint and apoptosis. Leuk Res 34: 364-372, 2010.

47. Hanahan D and Weinberg RA: Hallmarks of cancer: the next generation. Cell 144: 646-674, 2011. 